Acta Technologica Agriculturae 4

Nitra, Slovaca Universitas Agriculturae Nitriae, 2016, pp. 110-116

\title{
EVALUATION OF THE IMPACT OF WEED CONTROL METHODS ON QUANTITATIVE AND QUALITATIVE CHARACTERISTICS OF MOLDAVIAN BALM; A MEDICINAL PLANT
}

\author{
Mohsen JANMOHAMMADI*, Naser SABAGHNIA, Adel BASHIRI \\ University of Maragheh, Iran
}

\begin{abstract}
Moldavian balm is an annual herbaceous plant and its lemon-scented leaves contain essential oil. However, weeds adversely affect its growth by release of allelochemicals, and/or direct competition for nutrient, moisture, light and space. Current experiment was conducted to evaluate the different weed control methods including preventive approach (soil pasteurization), mechanical methods (one hand weeding, two hand weeding, and successive hand weeding for weed free condition), and chemical control by synthetic herbicides (haloxyfop-R-methyl and trifluralin). Results revealed that stem diameter, quantity of secondary branches, flower-bearing branches and leaves were significantly affected by weed control treatments; the highest lateral growth was obtained by successive mechanical weed control and two hand weeding method, respectively. This trend was also observed in canopy spread and chlorophyll content. Pre-emergence control by trifluralin considerably accelerated the initiation of flowering in Moldavian balm. However, observation of qualitative traits showed that the highest essential oil content and oil yield was obtained when the plants grew in weed free soil which was pasteurized. Considering the recognized essential oils, the most responsive composition was including Geranial, Geranyl acetate, Neral and Geraniol. The lowest amount of Neral was recorded in postemergence control performed by means of haloxyfop-R-methyl herbicide.
\end{abstract}

Keywords: chemical herbicides; essential oil; mechanical control; oil components; soil solarization

Moldavian balm (Dracocephalum moldavica L.), an annual aromatic herb belonging to Lamiaceae family, has antioxidative properties and can be used as food and medicinal beverage (Dastmalchi et al., 2007). Aboveground organs of this plant contain various secondary metabolites such as phenolic compounds (flavonoids), essential oils and etc. which are responsible for medicinal characteristics of this plant (Dastmalchi et al., 2007; Yousefzadeh et al., 2013; Yang et al., 2014). However, the presence of weeds may lead to a decrease in both yield and quality of medicinal plants (Carrubba and Militello, 2013). It is recognized that adverse effects of weed are more damaging than any category of agricultural pests suchasinsects, nematodes, diseases, rodents, etc., the damaging impact is estimated to approximately $45 \%$ and it may be more or less equal to whole production in the case of medicinal plants (Upadhyay et al., 2012). Despite the availability of high-tech solutions (e.g. selective herbicides and genetically-modified herbicide-resistant crops) for certain varieties of crop plants, there is not enough information about the weed control in medicinal plants under field conditions even in the developed countries (Tu et al., 2001). On the other hand, in developing countries, suitable chemical herbicides are seldomly accessible at a reasonable price, hence farmers often must rely on substitute methods for weed management strategies. Furthermore, tendency to reduce the use of herbicides is rising and it refers to the importance of other non-chemical methods (Cauwer et al., 2014). A little success in weed managements is undoubtedly the consequence of an over-simplification of problem solving. Too much attention was paid to the development of weed management strategies (particularly to chemical herbicides) as solution for any weed difficulties, while the significance of other methods or integrated strategies (e.g. preventive, cropping or cultural, mechanical, biological and chemical methods) in a medicinal plant production system has been unnoticed. For very long

However, there are different methods for weed control in agricultural systems. It should be taken into account that weed control is always strictly embedded in crop management itself. As such, the interactions between weed management and other cultural practices must be both duly taken into account (Barber, 2003). Preventive methods include crop rotation, cover crops (when used as green manures or dead mulches), tillage systems, seed bed preparation, soil solarization, management of drainage and irrigation systems and of crop residues. Cultural methods include proper timing of crop sowing and spatial arrangement, crop genotype choice, cover crops (when used as living mulches), intercropping, and crop fertilization. However, curative methods include chemical, physical proceedings (e.g. mechanical and thermal) and biological methods used for direct weed control in an already established crop (Tu, 2001; Barberi, 2003).

Manual or mechanical weeding is definitely the most instantly applicable technique for weed control when the application of chemicals is not possible (Chicouene, 2007). However, one of the greatest limitation in mechanical weed control is represented by spatial arrangement, seeding rate and accessibility of mechanical equipment (Carrubba and Militello, 2013). These methods can be used for control 
of certain invasive plants, particularly if the population is relatively small. These techniques can be extremely efficient because they are oriented only on the weed and thus minimizing damage to desirable plants and animals, but they are generally labourious and time-consuming.

Keeping the above points in view, the question whether the utilization of chemical herbicides can be put into practice for weed control in medicinal plants is frequently asked. So there is little information related to weed control in medicinal plants. When chemical herbicides are applied for weed control under field conditions, both crop plants and weeds may absorb the herbicide compound in various amounts (Maas, 1977; Carrubba and Militello, 2013). Thus, the chemical herbicides may affect the metabolic processes in medicinal plants in positively or negatively. Such impact may be visible, but not always. Several secondary influences on the medicinal plants can be: changes in colour, growth retardation, and changing of the contents of nitrogen, nitrates, carbohydrates, and last but not least the biochemical quality (Upadhyay et al., 2012). Commonly, such secondary influences do not last very long and have hardly an effect on the final product. In this regard, Wang et al. (2000) reported that application of haloxyfop herbicides slightly affects the growth of Bupleurum falcatum as a medicinal plant, but efficiently kills weeds of many kinds. They also found out that Butralin was an effective herbicide for controlling the weeds from Gramineae family.

Likewise, the application of soil pasteurization or solarization technique for weed control is proven method, but it is in experimental stage. Soil pasteurization is nonchemical method for weed control by means of high temperatures produced by captured radiant energy from the sun (Marenco and Lustosa, 2000). This technique involves heating of soil by covering it with a clear plastic tarp for one or more months during a hot period of the year when the soil receives the most direct sunlight. The aim of this is to determine the impacts of different weed control approaches on quantitative and qualitative traits and essential oil content of Moldavian balm in highland area in north-western Iran.

The experiments presented here were carried out at the research field of College of Agriculture, University of Maragheh ( $\left.37^{\circ} 23^{\prime} \mathrm{N} ; 46^{\circ} 16^{\prime} \mathrm{E}\right)$, Maragheh, in north-west of Iran. Field was located at an altitude of 1485 meter from sea level, where the climate is semi-arid and with cold temperature. The experiment was performed on a silty loam soil ( $25 \%$ clay, $51 \%$ silt and $24 \%$ sand) with $\mathrm{pH} 8.07$, organic matter content $0.92 \%$, total nitrogen $0.13 \%, \mathrm{CaCO}_{3}$

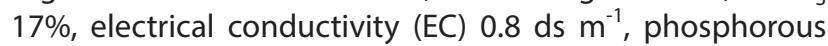
$15.31 \mathrm{ppm}$ and potassium $820 \mathrm{ppm}(0 \mathrm{~cm}$ to $60 \mathrm{~cm}$ in depth). Maragheh has an average annual rainfall of $375 \mathrm{~mm}$ consisting of $73 \%$ rain and $27 \%$ snow that falls during winter and early spring. In general, rainfall is not well-distributed through the year and the occurrence of rainfall during the late winter and early spring is frequent, approximately 10 days per month on the average. Rainfall from June through October is relatively rare and the highest rate of evapotranspiration can be recordable. Hence, application of the irrigation is necessary in this region. Monthly meteorological data including temperature, relative humidity, evapotranspiration, and rainfall for growing season is shown in Table 1.

\section{Material and methods}

Trifluralin $\left(\mathrm{C}_{13} \mathrm{H}_{16} \mathrm{~F}_{3} \mathrm{~N}_{3} \mathrm{O}_{4} ; \quad\right.$ 2,6-Dinitro-N, N-dipropyl-4(trifluoromethyl)) aniline is a selective, pre-sowing or preemergence herbicide used to control many annual grasses and broadleaf weeds in a large variety of crops. Trifluralin belongs to the dinitroaniline group and prevents weed growth by inhibiting root development through the interruption of mitosis and cell division. Trifluralin (EC 48\%) was mixed with water $\left(100 \mathrm{~L} \mathrm{ha}^{-1}\right)$ and was incorporated to soil within 4 hours after utilization, 20 days before sowing. Haloxyfop-P-methyl is selective herbicide (for the control of grass weeds in broad leaf), absorbed by the foliage and roots, and hydrolysed to haloxyfop, which is translocated to meristematic tissues, and inhibits their growth. Haloxyfop-R-methyl (EC 10.8\%) was applied as systemic post emergence control at 30 DAS by foliar spraying. Herbicide was diluted with water (at $100 \mathrm{~L} \mathrm{ha}^{-1}$ rate), and sprayed over the foliage to point of run-off (until every leaf is wetted, but not dripping). The field was kept under constant observation from sowing till harvesting.

Four weeks before the beginning of mulching and weed control, the area was mouldboard-ploughed and disked. The experiment was carried out as a randomized complete block design with three repetitions. They comprised of seven weed management treatments including $T_{1}$ : one hand weeding at 20 days after sowing (DAS); $T_{2}$ : two hand weeding at 20 and $40 \mathrm{DAS} ; \mathrm{T}_{3}$ : weed free (successive hand weeding at 10 days interval until harvest to maintain weed-free fields); $T_{4}$ : no weeding (control), $\mathrm{T}_{5}$ : trifluralin herbicide (pre-emergence control, $2.5 \mathrm{~L} \mathrm{ha}^{-1}$ ); $\mathrm{T}_{6}$ : haloxyfop-R-methyl herbicide (post emergence control, $1 \mathrm{~L} \mathrm{ha}^{-1}$ ); $\mathrm{T}_{7}$ : soil pasteurization (use of pure polyethylene). Net plot size was as $30 \mathrm{~m}^{2}$ (6,5 m). Solarization is most effective when the plastic sheeting (tarp) is laid as close as possible to a smooth soil surface. For pasteurization treatments, plastic films were laid on the smoothed beds after secondary soil cultivation, they were stretched close to the soil surface for four weeks before sowing, and their edges and

Table 1 Metrological data for the Moldavian balm during growing season at Maragheh station

\begin{tabular}{|l||c|c|c|c|c|c|}
\hline & $\begin{array}{c}\text { Minimum } \\
\text { temperature }\left({ }^{\circ} \mathbf{C}\right)\end{array}$ & $\begin{array}{c}\text { Maximum } \\
\text { temperature }\left({ }^{\circ} \mathbf{C}\right)\end{array}$ & $\begin{array}{c}\text { Mean } \\
\text { temperature }\left({ }^{\circ} \mathbf{C}\right)\end{array}$ & $\begin{array}{c}\text { Precipitation } \\
\text { amount (mm) }\end{array}$ & $\begin{array}{c}\text { Mean } \\
\text { humidity (\%) }\end{array}$ & $\begin{array}{c}\text { Actual crop } \\
\text { evapotranspiration (mm) }\end{array}$ \\
\hline March & 2.4 & 14.7 & 9 & 11.9 & 45.7 & 52.38 \\
\hline April & 6.6 & 20 & 14 & 20.83 & 42.8 & 70.08 \\
\hline May & 10.6 & 23.7 & 17.7 & 18.03 & 43.9 & 88.39 \\
\hline June & 16.6 & 30.6 & 24.5 & 7.2 & 27.7 & 107.50 \\
\hline July & 18.2 & 31.2 & 25.9 & 0 & 35 & 120.74 \\
\hline
\end{tabular}


ends were buried in trenches $10 \mathrm{~cm}$ deep and covered with soil. At the end of the period of pasteurization, the films were removed without soil disturbance.

Seeds of landrace Bonab were obtained from the West Azerbaijan Agriculture and Natural Resource Research Center. Seeds were planted by hand on 21 April 2014 at a rate of $1 \mathrm{~g}$ of seeds per $1 \mathrm{~m}$ in a row, and then the plants were thinned at the four-leaf stage to achieve an appropriate density. Row spacing was $30 \mathrm{~cm}$ and intra row spacing was $10 \mathrm{~cm}$. There was no incidence of pest or dragonhead disease during the experiment. Surface irrigation was applied for nine times during the growth season and the plots were irrigated to $70 \%$ of field capacity. All necessary cultural practices were followed uniformly for all the plots during the entire period of experimentation. At early flowering stage, chlorophyll index was measured in ten leaves of a plant at each plot, using a portable chlorophyll meter (SPAD). In average, the canopy is wide as the average of the lengths of longest spread from edge to edge across the canopy and it is at its widest at perpendicular to the first cross-section through the central mass of the canopy. The crop was harvested on July 27 (at $50 \%$ flowering). After harvesting, some of morphological traits such as plant fresh weight, dry weight of inflorescences, leaf number, number of lateral branches, number of flowering branches, number of flowers per plant, length of flower organ in main stem, height of the first flowering branch, plant heights, lateral stem number, stem diameter and fresh and dry weight of leaves were measured in ten plants from the middle of the plots. Fresh and dry weight plants were measured by means of digital weighing scales.

For evaluating the qualitative parameter, the plants were cut at ground level and samples of plants were dried in the shade and extraction of essential oils was conducted according to Yousefzadeh et al. (2013). Gas chromatography (GC) analysis was performed using a Thermo-UFM Ultra Fast gas chromatograph equipped with a DB-5 fusedsilica column ( $10 \mathrm{~m} 0.1 \mathrm{~mm}$ i.d., film thickness $0.40 \mu \mathrm{m})$. The oven temperature was held at $60{ }^{\circ} \mathrm{C}$ for 3 minutes, and then it was programmed to increase the temperature to $280^{\circ} \mathrm{C}$ at a rate of $80^{\circ} \mathrm{C}$ per $\mathrm{min}^{-1}$. The temperatures of the injector and flame-ionisation detector were held at $285^{\circ} \mathrm{C}$. Helium was used as carrier gas with a linear velocity of $32 \mathrm{~cm} \mathrm{~s}^{-1}$. The oils were injected manually into the GC instrument without dilution. The percentages of compounds were calculated by using the area normalisation method, without consideration of response factors. Gas chromatography-mass spectroscopy (GC-MS) were carried out using a Varian 3400 GC-MS system equipped with a DB-5 fused silica column ( $30 \mathrm{~m} 0.25 \mathrm{~mm}$ i.d., film thickness $0.25 \mu \mathrm{m}$ ). After injection, the oven temperature was increased from $50{ }^{\circ} \mathrm{C}$ to $240^{\circ} \mathrm{C}$ at a rate of $4{ }^{\circ} \mathrm{C} \mathrm{min}{ }^{-1}$, the temperature of the transfer line was maintained at $260^{\circ} \mathrm{C}$, and the linear velocity of the helium carrier gas was maintained at $31.5 \mathrm{~cm} \mathrm{~s}^{-1}$, with a split ratio of $1: 60$, an ionisation energy of $70 \mathrm{eV}$, a scan time of $1 \mathrm{~s}$, and a mass range from 40 amu to $300 \mathrm{amu}$ (Yousefzadeh et al., 2013). The components of the oils were identified by comparing their mass spectra with those held in a computer library or samples obtained using authentic compounds. The identities of the components were confirmed by comparing their retention indices, either with those of authentic compounds or with data published in the literature (Adams, 1995).
Analysis of variances and comparison of mean values were performed using SAS computer program and least significant difference (LSD) test was utilized for the mean comparisons. Correlation analysis and principal component analysis (PCA), based on the rank correlation matrix and biplot analysis were performed by means of SPSS ver. 16, STATISTICA ver. 8 and Minitab ver.16.

\section{Results and discussion}

Analysis of variance showed that stem diameter was significantly affected by weed control management $(p \leq 0.01)$. The thickest stem was related to plant grown under successive hand weeding, however, there was no significant difference between weed free condition, two hand weeding and both chemical control methods. The lowest value of stem diameter was recorded under no-weeding and one hand weeding condition. Chlorophyll content of Moldavian balm considerably responded to weed control methods, the highest chlorophyll content was recorded in plants grown under successive hand weeding and followed by two hand weeding (Figure 1). The lowest amount of chlorophyll was observed in control and post emergence herbicides application. In line with our results, Monjezi et al. (2015) concluded that foliar application of post-emergence herbicide significantly reduced the chlorophyll content in Valeriana officinalis. The findings of the current study are consistent with those of Nethra and Jagannath (2011) who found that post emergence herbicide (oxadiagryl) noticeably reduced the chlorophyll content in sunflower and maize.

Evaluation of plant fresh weight showed that this trait was significantly affected by weed control treatments, so the lowest amount was recorded for plant under no weeding (control) condition, while the maximum value of fresh weight was recorded under soil pasteurization and successive hand weeding (Figure 2). Field monitoring during growth season also revealed that soil pasteurization might inhibit the emergence of lots of annual weeds, especially at the top layer, because temperature increases more slowly at deeper levels. It is encouraging to compare this figure with that found by Marenco and Lustosa (2000) who reported that 15-45 days long solarization efficiently controlled annual weeds in Brazil and its impact was noticeable after one year. Haloxyfop inhibits the acetyl-CoA carboxylase $\left(\mathrm{ACC}_{\text {ase }}\right.$ ) that is needed for fatty acid synthesis and the subsequent production of phospholipids which are essential for plant cell membrane. However, Yousefi and Rahimi (2014) applied haloxyfop and pendimethalin herbicides to fennel (Foeniculum vulgare Mill.) and reported that both herbicides provided certain weed control without any damage to the crop, but pendimethalin was more efficient. However, observation of plant dry weight showed that there is not any significant difference between plant grown under both soil pasteurization and chemical control methods. This may indicate that superiority of fresh weight under soil pasteurization is due to succulent growth. However the highest dry weight value was recorded under weed free condition.

The results revealed that plant height and height of the first flowering branch were not affected by weed control treatments. Vice versa, the number of leaves considerably 
responded to weed control ( $p \leq 0.01$ ), so the plants under no-weeding condition showed the lowest quantity of leaves. Plant under successive and two hand weeding had the highest quantity of leaves, respectively (Figure 3). A similar trend was also observed for canopy spread. Regarding

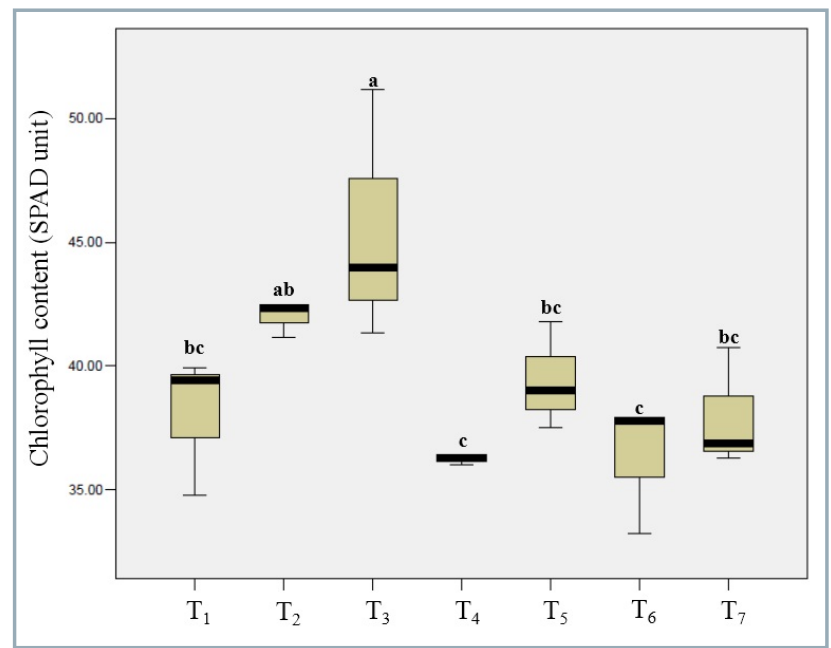

Figure 1 Impacts of different weed control methods on chlorophyll content in leaves of Moldavian balm (Dracocephalum moldavica) cultivated in highland semi-arid region of Maragheh $\mathrm{T}_{1}$ : one hand weeding at 20 days after sowing (DAS); $\mathrm{T}_{2}$ : two hand weeding at 20 and $40 \mathrm{DAS} ; \mathrm{T}_{3}$ : weed free (successive hand weeding at 10 days interval until harvest to maintain weed-free fields); $\mathrm{T}_{4}$ : no weeding (control), $\mathrm{T}_{5}$ : trifluralin herbicide (pre-emergence control); $\mathrm{T}_{6}$ : haloxyfop-R-methyl herbicide (post emergence control,); $T_{7}$ : soil pasteurization (use of clear polyethylene; solarization). Values with the same letter were not significantly different. Error bars show standard error of the mean

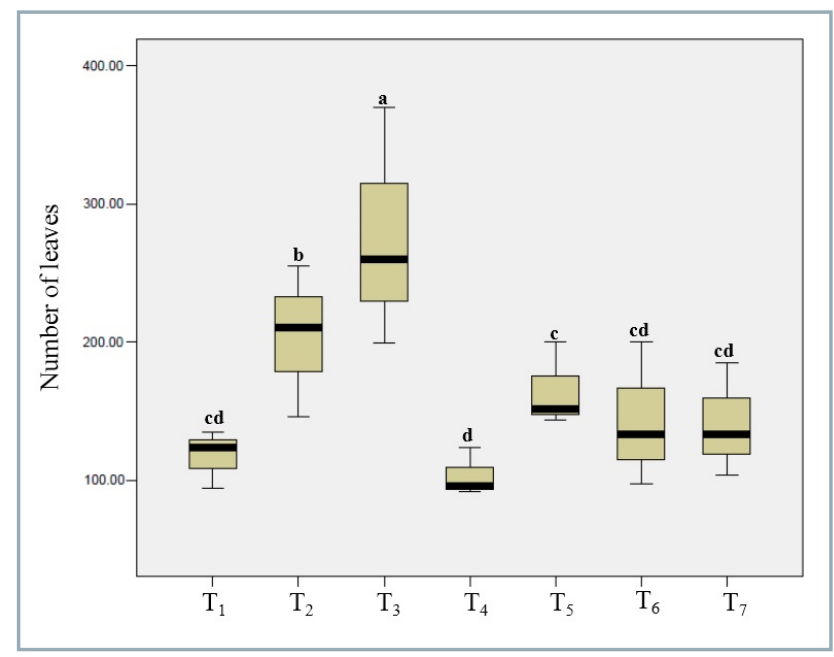

Figure 3 Impacts of different weed control methods on quantity of leaves in Moldavian balm (Dracocephalum moldavica) cultivated in highland semi-arid region of Maragheh

Values with the same letter were not significantly different. $T_{1}$ : one hand weeding; $T_{2}$ : two hand weeding; $T_{3}$ : weed free (successive hand weeding); $\mathrm{T}_{4}$ : no weeding (control), $\mathrm{T}_{5}$ : trifluralin herbicide; $\mathrm{T}_{6}$ : haloxyfop-R-methyl herbicide; $T_{7}$ : soil pasteurization. Error bars show standard error of the mean this issue, it can be stated that weed plants have a high relative growth rate and it allows weeds to rapidly occupy space and capture resources and reduce the time between vegetative growth and reproduction. The results indicated that successive hand weeding allowed Moravian balm to

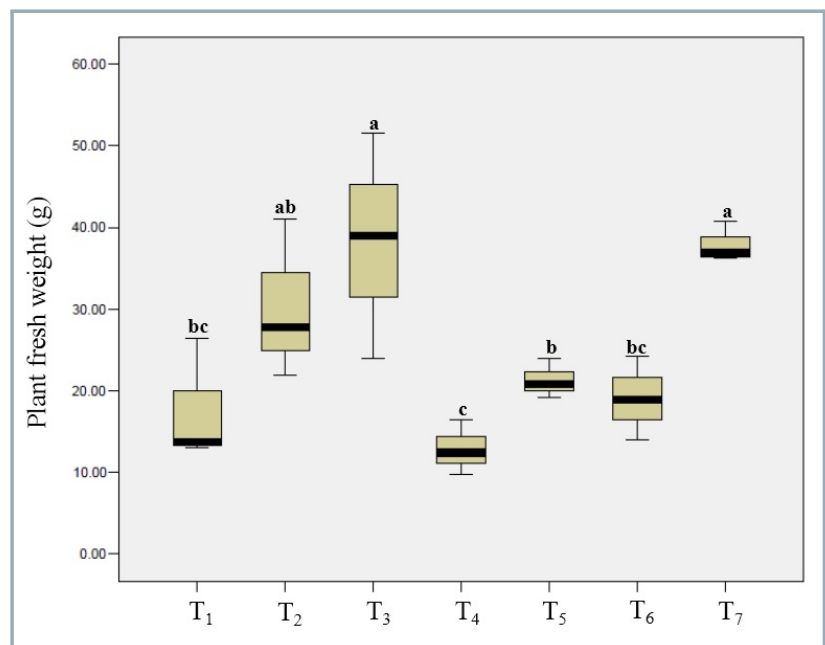

Figure 2 Impacts of different weed control methods on fresh weight of Moldavian balm (Dracocephalum moldavica) grown in highland semi-arid region of Maragheh

$\mathrm{T}_{1}$ : one hand weeding; $\mathrm{T}_{2}$ : two hand weeding; $\mathrm{T}_{3}$ : weed free; $T_{4}$ : no weeding (control), $T_{5}$ : trifluralin herbicide (pre-emergence control); $\mathrm{T}_{6}$ : haloxyfop-R-methyl herbicide (post emergence control,); $\mathrm{T}_{7}$ : soil pasteurization. Means followed by the same letter do not significantly differ $(p \leq 0.05$, LSD). Error bars show standard error of the mean

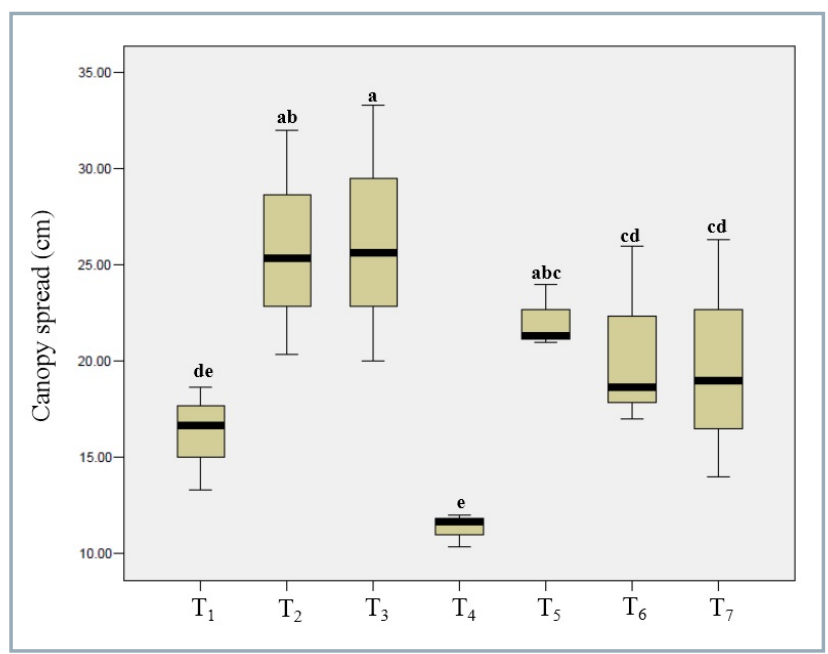

Figure 4 Impacts of different weed control methods on canopy spread of Moldavian balm (Dracocephalum moldavica) cultivated in highland semi-arid region of Maragheh

$\mathrm{T}_{1}$ : one hand weeding at 20 days after sowing (DAS); $\mathrm{T}_{2}$ : two hand weeding at 20 and $40 \mathrm{DAS} ; \mathrm{T}_{3}$ : weed free (successive hand weeding at 10 days interval until harvest to maintain weed-free fields); $\mathrm{T}_{4}$ : no weeding (control), $\mathrm{T}_{5}$ : trifluralin herbicide (pre-emergence control); $\mathrm{T}_{6}$ : haloxyfop-R-methyl herbicide (post emergence control,); $\mathrm{T}_{7}$ : soil pasteurization. Means followed by the same letter do not significantly differ $(p \leq 0.05$, LSD). Error bars show standard error of the mean 
dominantly occupy the space and it produced the higher canopy (Figure 4). Compared to no-weeding condition, almost all weed control treatments could improve quantity of leaves and size of the canopy. When resources are limited, minimization of loss of previously captured resources may be as important in maintaining resource levels as the capture of new resources (Sheley and Krueger-Mangold, 2003). Under these conditions, maximization of quantity of leaves and canopy growth by means of increasing the quantity of lateral branches may be favoured.

Essential oil content of Moldavian balm was significantly affected by weed control treatments $(p \leq 0.01)$, so the highest value was obtained from plant grown under weed free condition and soil pasteurization (Figure 5). Our results showed that the there is no significant difference between chemical control and control condition; however, these results differ from Mahey et al. (2001) who reported that chemical methods are more efficient than hand weeding for improving the herbage and oil content of Mentha arvensis L. Furthermore, evaluation of oil yield revealed that plant under weed free condition had the highest oil yield that was followed by two hand weeding (Figure 6). In this context, it is remarkable to note that plant under post emergence herbicide treatment had higher oil yield than pre-emergence herbicide treatment. However, considering the fact of small sample size, caution must be paid because the findings might not be transferable to all conditions. Generally, it seems that weed control by means of reduction in competition increase the availability of required resources such as nutrient and water that would eventually lead to increase in growth and oil yield. Increase in the above ground dry matter of winter wheat due to the good weed control by means of the sethoxydim application was observed by Bidlack et al. (2006) as compared with the untreated control. Qasem and Foy (2006) also reported

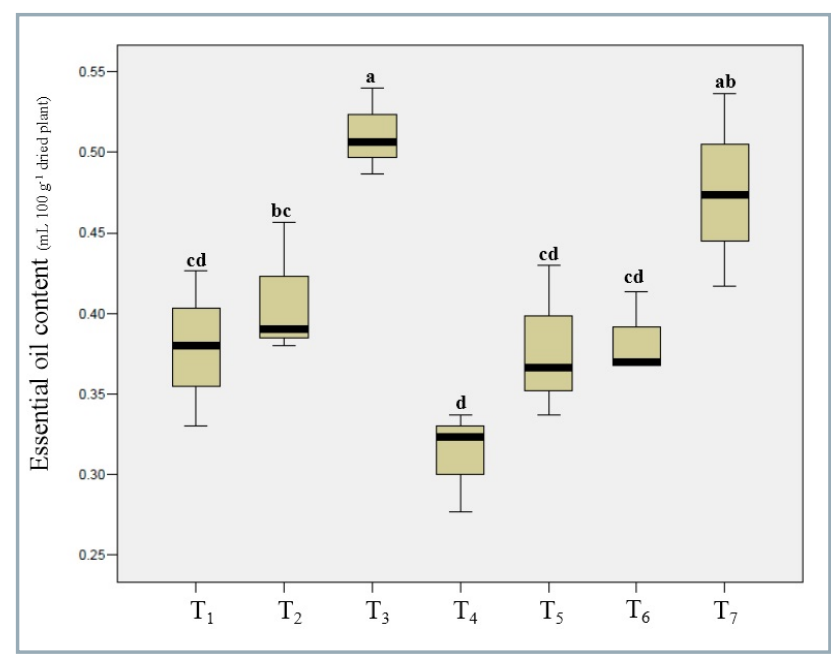

Figure 5 Impacts of different weed control methods on essential oil content of Moldavian balm (Dracocephalum moldavica) cultivated in highland semi-arid region of Maragheh $T_{1}$ : one hand weeding, $T_{2}$ : two hand weeding; $T_{3}$ : weed free (successive hand weeding); $\mathrm{T}_{4}$ : no weeding (control), $\mathrm{T}_{5}$ : trifluralin herbicide (pre-emergence control); $\mathrm{T}_{6}$ : haloxyfop-R-methyl herbicide (post emergence control); $\mathrm{T}_{7}$ : soil solarization. Values with the same letter were not significantly different that utilization of oxadiazon and oxyfluorfen increased the biomass of Syrian marjoram (Origanum syriacum L.).

The results of both GC and GC-MS analyses of essential oils of dragonhead plants revealed that the major constituents of the oil were Neral, Geraniol, Geranial, and Geranyl acetate. In average, these components represent $17.88 \%, 19.27 \%, 26.26 \%$ and $23.11 \%$ of the oils that were extracted from plants, respectively. This also accords with earlier reports that indicated that the main components of essential oils extracted from dragonhead plants are Geraniol, Geranial, Geranyl acetate, Neryl acetate, cis-Chrysanthenol and $\beta$-Pinene. (Janmohammadi et al., 2014; Yousefzadeh et al., 2013). The highest amount of Geranial was recorded for plant under trifluralin application and the lowest amount was related to soil pasteurization condition (Figure 7). Plant cultivated under halxyfop application showed that

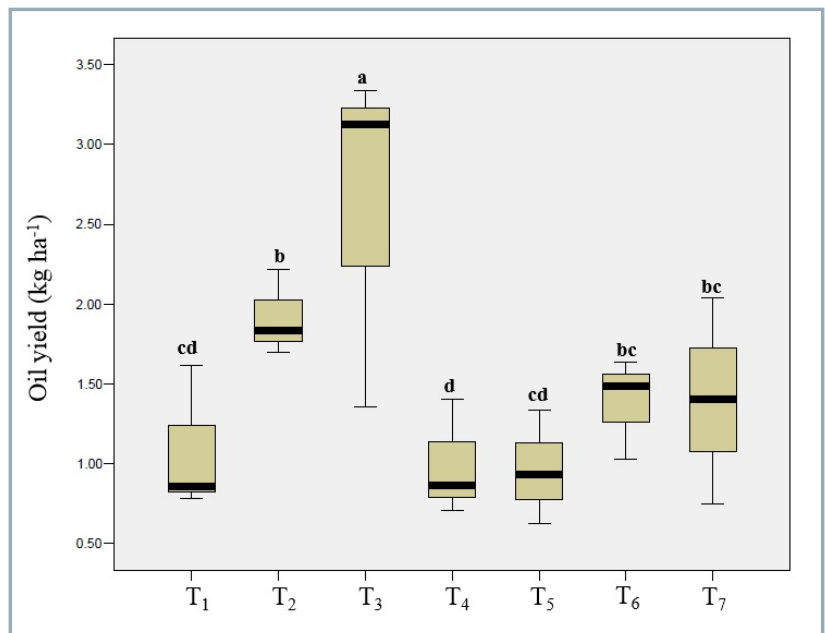

Figure 6 Impacts of different weed control methods on essential oil yield of Moldavian balm (Dracocephalum moldavica) cultivated in highland semi-arid region of Maragheh $\mathrm{T}_{1}$ : one hand weeding; $\mathrm{T}_{2}$ : two hand weeding; $\mathrm{T}_{3}$ : weed free; $T_{4}$ : no weeding (control), $T_{5}$ : trifluralin herbicide (pre-emergence control); $\mathrm{T}_{6}$ : haloxyfop-R-methyl herbicide (post emergence control,); $\mathrm{T}_{7}$ : soil pasteurization. Means followed by the same letter do not significantly differ $(p \leq 0.05)$. Error bars show standard error of the mean

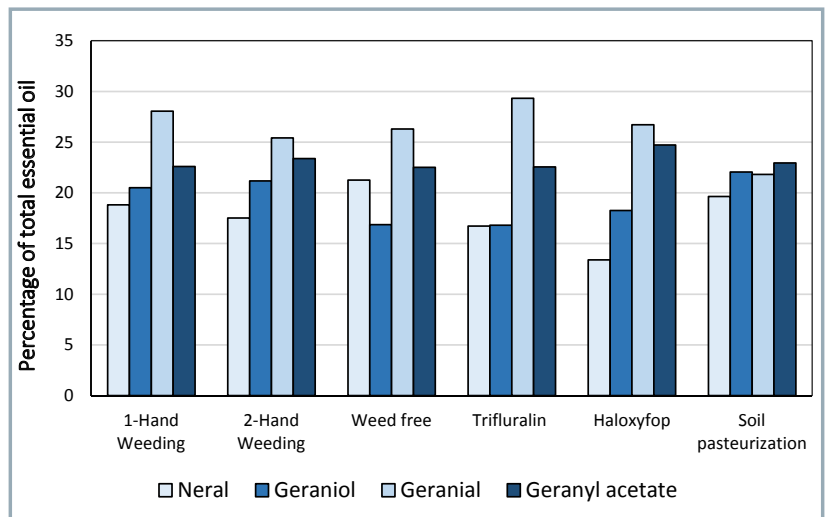

Figure 7 Effect of different weed control methods on main oil components of Moldavian balm (Dracocephalum moldavica) grown in highland semi-arid region of Maragheh 
it contained the highest amount of Geranyl acetate. However, application of chemical herbicides considerably reduced the amount of Neral and Geranial as compared to control, and this state was more prominent for Neral. It have been revealed that Geraniol can be synthesized by Geraniol synthesis

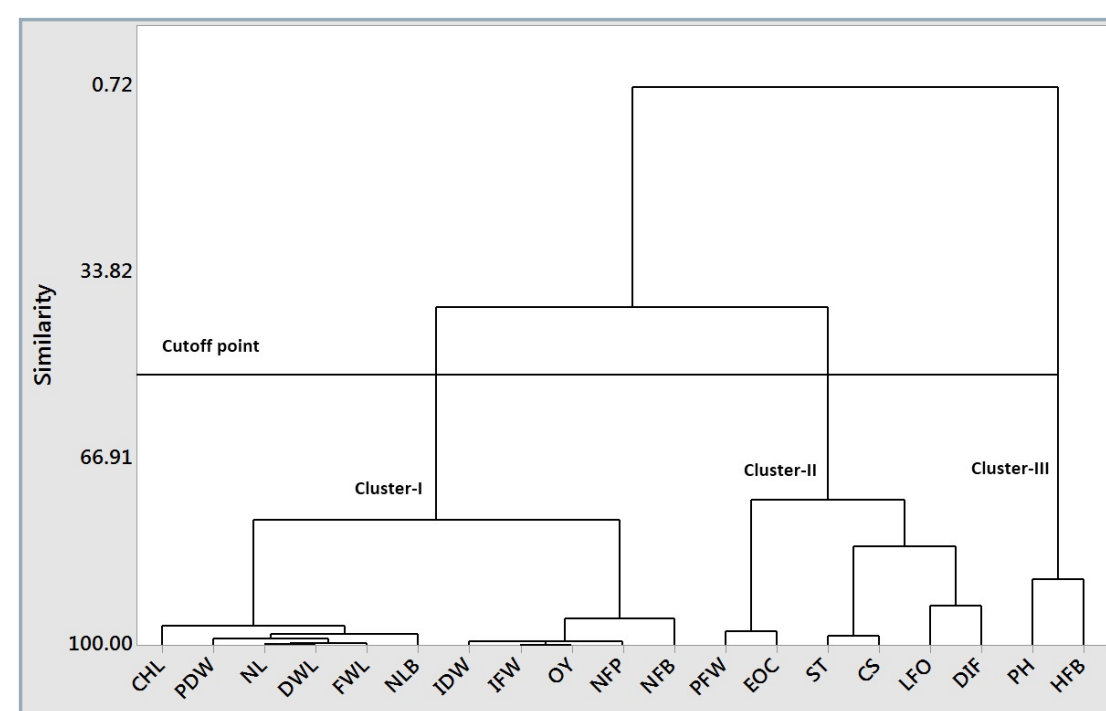

Figure 8 Cluster analysis of agronomic and morpho-physiological traits in Moldavian balm (Dracocephalum moldavica) cultivated in semi-arid region of Mragheh

Abbreviation: PFW: plant fresh weight; PDW: plant dry weight; IFW: Fresh weight of inflorescences, IDW: dry weight of inflorescences; PH: plant height; NL: number of leaves; NLB: number of lateral branches; NFB: number of flowering branches; NFP: number of flowers per plant; ST: stem diameter $(\mathrm{cm})$; LFO: length of flower organ in main stem; CS: canopy spread, HFB: height of the first flowering branch; DIF: number of days from planting to initiation of flowering; FWL: fresh weight of leaves; DWL: dry weight of leaves; CHL: chlorophyll content; EOC: essential oil content; OY: Oil yield

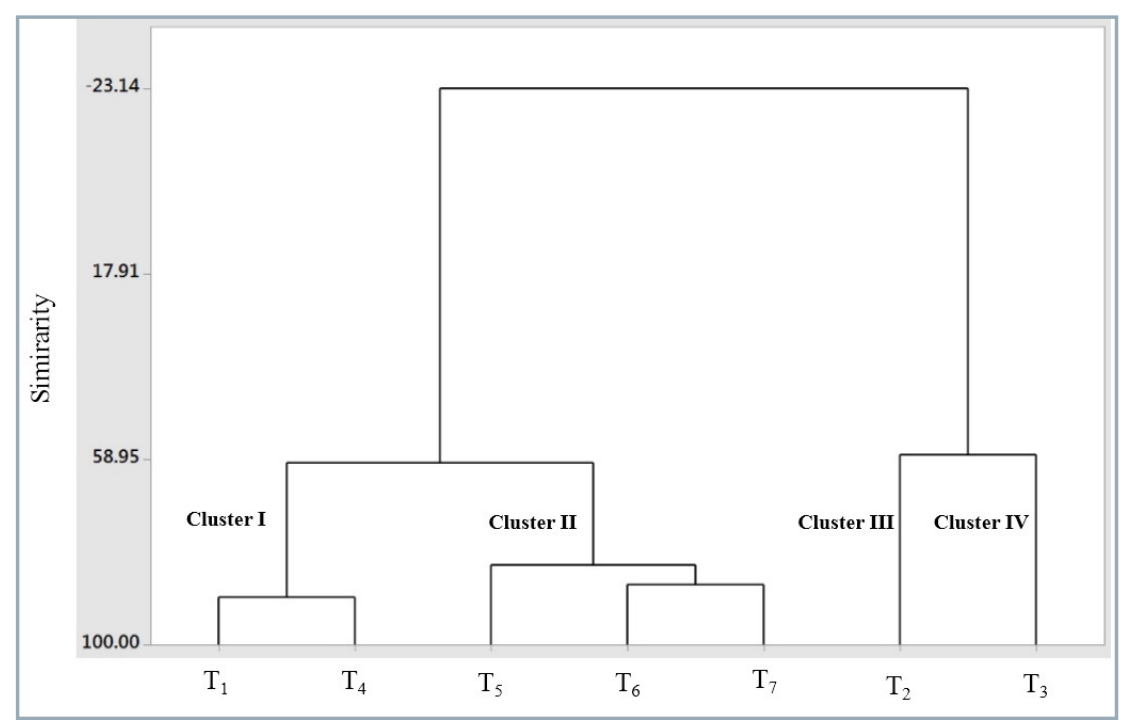

Figure 9 Cluster analysis of different weed control treatments according to similarity of their impacts on qualitative and quantitative traits Moldavian balm

$T_{1}$ : one hand weeding; $T_{2}$ : two hand weeding; $T_{3}$ : weed free; $T_{4}$ : no weeding (control), $T_{5}$ : trifluralin herbicide (pre-emergence control); $T_{6}$ : haloxyfop- $R-$ methyl herbicide (post emergence control); $\mathrm{T}_{7}$ : soil solarization
To better understand the relationships between the measured traits of Moldavian balm, the relationships are displayed in clusters (Figure 8). Cluster analysis of traits showed that the dendrogram was divided into three clusters. Cluster I consisted of chlorophyll content, plant dry weight, quantity of leaves, fresh weight of leaves, dry weight of leaves, number of lateral branches, fresh weight of inflorescences, dry weight of inflorescences, oil yield, quantity of flowers per plant, number of flowering branches which were considerably increased by means of two and successive hand weeding and their response to the fertilizers was somewhat different from other traits and this was especially proven for chemical control condition. For this cluster, the post emergence herbicide (haloxyfop-R-methyl) was more efficient than chemical pre-emergence control (Trifularin). Cluster II contained the plant fresh weight, essential oil content, stem diameter, canopy spread, length of flower organ in main stem, quantity of days from planting to initiation of flowering; the majority of these traits showed a high correlation with oil content. This group is a suitable indicator for evaluation of the impacts of weed control methods. Canopy spread in particular is easy to measure and nondestructive trait. Cluster III included the plant height and height of the first flowering branch which were not affected by weed control treatments.

Cluster analysis was also used to determine the impacts of the treatments on evaluated traits. Cluster analysis of treatments showed that the dendrogram was divided into three groups (Figure 9). Group I included $T_{1}$ (one hand weeding at 20 days after sowing) and $\mathrm{T}_{4}$ (no weeding; control), which showed the lowest vegetative growth and oil content. These results indicate the importance of the weed control in Moldavian balm. Group II included $\mathrm{T}_{5}$ (trifluralin herbicide; pre-emergence control), $\mathrm{T}_{6}$ (haloxyfopR-methyl herbicide) and $T_{7}$ (soil solarization). Although these methods statistically improved the growth performance of medicinal plants, they failed to provide the best results. Group III included two and successive hand weeding, respectively. The mentioned treatments resulted in best growth, 
highest plant dry weight and oil quality. Nonetheless, two technologies that appear especially appropriate for foliar spraying of chemical herbicides are to be mentioned. The first is the use of electrostatic sprayers; these sprayers are imparted with charge and thus they distribute the particles more easily to plants. The second technology uses sound to increase the leaves, herbicide absorption. However, due to unknown effects of chemical herbicides, the utilization of modern mechanical weed control equipment is vital. Available or developing technologies for mechanical weed control that use sensors and powerful computing systems are pill cameras that are remote controlled for movement in the digestive system with muscular contractions; OnStar, which can open and close car locks remotely; multi-energy X-ray imaging technology for use at airports; and sensors capable of detecting drugs in breath and monitoring hand hygiene by detecting soap fumes.

\section{Conclusion}

Medicinal plants have played an important role in numerous ancient traditional systems of medicine, therefore, applying the appropriate agronomic management options to maintain their high quality is vital. Results of current study showed that weeds as unwanted and undesirable plants can interfere in the utilization of natural resources and adversely affect both qualitative and qualitative aspect of Moldavian balm. Although the application of chemical herbicides could improve the growth of Moldavian balm to certain level, the best performance was observed for plant cultivated under successive weeding. These findings refer to the point that Moldavian balm is very susceptible to weeds and to achieve acceptable quantity and quality, the weeds must be controlled frequently. Considering the superiority of the mechanical control, use the appropriate equipment is essential. Our results revealed that chemical herbicides can significantly affect the essential oil composition, so the highest amount of Geranial was recorded in plants cultivated under trifluralin herbicide application (pre-emergence control). It seems that both medicinal plants and weed may absorb the compound in different amounts. Due to the uncertain impacts of chemical weed control, more attention should be paid to mechanical and environmentally friendly methods for cultivation of medicinal plants. Considering the growing demand for medicinal plants with each passing years, weed management methods should be selected cautiously.

\section{Acknowledgements}

The authors would like to thank the university of Maragheh for financial support of this study. The authors are grateful to S. Solatani and A. Ezati for their field and technical assistance. The authors are also thankful to Dr. S. Yousefzadeh for his valuable advices regarding the chemical analysis.

\section{References}

ADAMS, R. P. 1995. Identification of essential oil components by gas chromatography/mass spectroscopy. Carol Stream, USA: Allured Publishing Corp. p. 16.

BARBERI, P. 2003. Preventive and cultural methods for weed management. FAO Plant Production and Protection Paper. FAO, Roma, Italy.
BIDLACK, J.E. - MIDDICK, A. - SHANTZ, D. - MACKOWN, C. T. - WILLIAMS, R. D. - RAO, S. C. 2006. Weed control in a pigeon pea-wheat cropping system. In Field crops research, vol. 96, 2006, no. 1, pp. 63-70.

CARRUBBA, A. - MILITELLO, M. 2013. Nonchemical weeding of medicinal and aromatic plants. In Agronomy for sustainable development, vol. 33, 2013, no. 3, pp. 551-561.

CAUWER, B. - FAGOT, M. - BEELDENS, A. - BOONEN, E. - BULCKE, R. REHEUL, D. 2014. Integrating preventive and curative non-chemical weed control strategies for concrete block pavements. In Weed Research, vol. 54, 2014, no. 1, pp. 97-107.

CHICOUENE, D. 2007. Mechanical destruction of weeds. A review. In Agronomy for sustainable development, vol. 27, 2007, no. 1, pp. 19-27. DASTMALCHI, K. - DORMAN, H. D. - LAAKSO, I. - HILTUNEN, R. 2007. Chemical composition and antioxidative activity of Moldavian balm (Dracocephalum moldavica L.) extracts. In LWT-Food Science and Technology, vol. 40, 2007, no. 9, pp. 1655-1663.

IIJIMA, Y. - GANG, D. R. - FRIDMAN, E. - LEWINSOHN, E. - PICHERSKY, E. 2004. Characterization of geraniol synthase from the peltate glands of sweet basil. In Plant Physiology, vol. 134, 2004, no. 1, pp. 370-379. JANMOHAMMADI, M. - ZAHED, S. M. - AHADNEZHAD, A. YOUSEFZADEH, S. - SABAGHNIA, N. 2014. Influence of chemical and organic fertilizer on growth, yield and essential oil of dragonhead (Dracocephalum moldavica L.) plant. In Acta Agriculturae Slovenica, vol. 103,2014 , no. 1 , pp. $73-81$.

MAAS, G. 1977. Weed control in medicinal plants. In I International Symposium on Spices and Medicinal plants., 1977, pp. 32-330.

MAHEY, R. K. - SINGH, A. - SINGH, R. - BRAR, L. S. 2001. Weed control in menthe species. In conservation and utilization of medicinal and aromatic plants, 2001, pp. $140-48$.

MARENCO, R. A. - LUSTOSA, D.C. 2000. Soil solarization for weed control in carrot. In Pesquisa Agropecuária Brasileira, vol. 35, 2000, no. 10, pp. 2025-2032.

MONJEZI, N. - RAZMJO, J. - KARIMMOJENI, H. 2015 Valerian (Valeriana officinalis $\mathrm{L}$.) tolerance to some post-emergence herbicides. In Journal of Plant Protection Research, vol. 55, 2015, no. 4, pp. 415-420.

NETHRA, N. S. - JAGANNATH, S. 2011. Phytotoxic effect of oxadiargyl on germination and early growth of sunflower (Helianthus annuus L.) and maize (Zea mays L.). In Archives of Phytopathology and Plant Protection, vol. 44, 2011, no. 19, pp.1901-1907.

QASEM, J. R. - FOY, C. L. 2006. Selective weed control in syrian marjoram (Origanum syriacum) with Oxadiazon and Oxyfluorfen herbicides. In Weed technology, vol. 20, 2006, no. 3, pp. 670-676.

SHELEY, R. L. - KRUEGER-MANGOLD, J. 2003. Principles for restoring invasive plant-infested rangeland. In Weed science, vol. 51, 2003, no. 2, pp. 260-265.

TU, M. - HURD, C. - RANDALL, J. M. 2001. Weed control methods handbook: tools \& techniques for use in natural areas. Wildland Invasive Species Team, 2001.

UPADHYAY, R. K. - BAKSH, H. - PATRA, D. D. - TEWARI, S. K. - SHARMA, S. K. - KATIYAR R. S. 2012. Integrated weed management of medicinal plants in India. In International Journal of Medicinal and Aromatic Plants, vol. 1, 2012, no. 2, pp. 51-56.

WANG, K. C. - YANG, W. Q. - WANG, Z. Y. 2000. Chemical weed control of medicinal plant Bupleurum falcatum L. In China journal of Chinese materia medica, vol. 25, 2000, no. 4, pp. 210-213.

YANG, L. N. - XING, J. G. - HE, C. H. - WU, T. 2014. The phenolic compounds from Dracocephalum moldavica L. In Biochemical Systematics and Ecology, vol. 54, 2014, pp. 19-22.

YOUSEFI, A. R. - RAHIMI, M. R. 2014. Integration of soil-applied herbicides at the reduced rates with physical control for weed management in fennel (Foeniculum vulgare Mill.). In Crop Protection, vol. 63, 2014, pp. 107-112.

YOUSEFZADEH, S. - MODARRES-SANAVY, S. A. M. - SEFIDKON, F. ASGARZADEH, A. - GHALAVAND, A. - SADAT-ASILAN, K. 2013. Effects of Azocompost and urea on the herbage yield and contents and compositions of essential oils from two genotypes of dragonhead (Dracocephalum moldavica L.) in two regions of Iran. In Food chemistry, vol. 138, 2013, no. 2, pp. 1407-1413. 